\title{
Smart Card Madani: Solusi Berbasis Komunikasi Inovasi pada Pemerintahan Kota Pekanbaru, Riau
}

\author{
Toni Hartono, Febby Amelia Trisakti, Gista Aprilia \\ Universitas Islam Negeri Sultan Syarif Kasim Riau \\ Email: toni.hartono@uin-suska.ac.id
}

Diterima : 06 April 2021

Disetujui : 11 Juni 2021

Diterbitkan : 21 Agustrus 2021

\begin{abstract}
Abstrak
Artikel ini hendak mendiskusikan eksistensi inovasi baru yang digagas pemerintah Kota Pekanbaru, yakni produk Smart Card Madani. Smart Card Madani merupakan salah satu inovasi dari program Smart City yang digadang-gadang mampu menjadi solusi permasalahan masyarakat perkotaan. Program ini dicanangkan oleh Pemerintah Kota Pekanbaru sejak tahun 2017. Smart Card Madani merupakan inovasi pemerintah Kota Pekanbaru yang diatur dalam UU No. 23 tahun 2014 tentang Pemerintahan Daerah bab XXI bertajuk Inovasi daerah pasal 386-390. Dalam undang-undang tersebut dikatakan bahwa pemerintah daerah harus melakukan inovasi yang menunjang pembangunan daerah. Program ini diyakini bisa menyelesaikan berbagai masalah perkotaan seperti pelayanan publik, kemacetan, penumpukan sampah, dan keamanan warga. Artikel ini disajikan untuk menjawab pelayanan publik yang dilakukan pemerintah Kota Pekanbaru melalui penggunaan Smart Card Madani. Studi ini menggunakan metode kualitatif dengan teknik pengumpulan data wawancara, observasi dan dokumentasi. Hasil studi ini menunjukkan bahwa inovasi program Smart Card Madani membantu pemerintah dalam memberikan pelayanan publik berbasis teknologi seperti mengganti uang tunai menjadi uang elektronik, sebagai alat transasksi nontunai di lembaga pendidikan, bandara, dan supermarket, serta sebagai alat untuk absensi bagi Aparatur Sipil Negara Pemerintah Kota Pekanbaru.
\end{abstract}

Kata Kunci: smart card, madani, inovasi, solusi

\begin{abstract}
This article intends to discuss the existence of a new innovation initiated by the Pekanbaru City government, namely the Madani Smart Card product. The Madani Smart Card is one of the innovations of the Smart City program which is predicted to be a solution to urban community problems. This program has been proclaimed by the Pekanbaru City Government since 2017. The Madani Smart Card is an innovation of the Pekanbaru City government which is regulated in Law No. 23 of 2014 concerning Regional Government chapter XXI entitled Regional innovation, articles 386-390. The law states that local governments must carry out innovations that support regional development. This program is believed to be able to solve various urban problems such as public services, congestion, garbage accumulation, and citizen safety. This article is presented to answer public services carried out by the Pekanbaru City government through the use of Madani Smart Cards. This study uses qualitative methods with interview data collection techniques, observation and documentation. The results of this study indicate that the Smart Card Madani program innovation helps the government in providing technology-based public services such as changing cash into electronic money, as a means of non-cash transactions at educational institutions, airports, and supermarkets, as well as a tool for attendance for City Government Civil Servants Pekanbaru.
\end{abstract}

Keywords: smart card, civilian, innovation, solutions 


\section{PENDAHULUAN}

Pada masa ini, kemajuan teknologi mampu mengubah gaya hidup masyarakat, dari konvensional ke digital (Nainggolan \& Sd, 2018). Transformasi digital memaksa sebuah kota dan pemerintah untuk dapat bersaing dengan negara dan wilayah lain (Meiwanda, 2020). Dengan perkembangan digitaliasi, pada akhirnya pola perilaku masyarakat mengalami pergeseran baik dari sisi budaya, etika dan norma (Cahyono, 2016). Pergeseran tersebut justru menimbulkan beragam permasalahan, baik menyangkut infrastruktur kota dan kemanusiaan. Permasalahan kota menstimulasi munculnya beragam ide untuk mengelola kota secara baik. Salah satu ide yang muncul sekira tahun 2009 adalah smart city, kota pintar. Menurut data penelitian, bahwa selama lima tahun terakhir, sejak tahun itu label smart city telah menyebar di seluruh dunia, dan berdampak pada strategi perkotaan di kota-kota besar dan kecil (Dameri and Sabroux, 2014).

Smart city hadir di perkotaan untuk menjawab permasalahan-permasalahan yang serius dan kompleks. Smart city dianggap mampu menghadapi permasalahan perkotaan yang semakin meningkat. Kini, setiap kota mulai menerapkan smart sity sebagai strategi untuk menyelesaikan permasalahan perkotaan secara terintegrasi. Sederetan masalah perkotaan menjadi pemicu hadirnya konsep ini, seperti banjir, penumpukan sampah di tengah kota, daerah aliran sungai yang tercemar, kemiskinan, pengangguran, menurunnya angka partisipasi pendidikan, kemacetan lalu lintas yang belum terselesaikan, dan pelayanan publik yang belum maksimal (Perdana, 2019). Smart city bertujuan untuk menentukan konsep tata letak kota yang cerdas dan berkarakter. Smart city pada intinya memiliki enam dimensi, yaitu ekonomi yang cerdas, mobilitas cerdas, lingkungan pintar, masyarakat cerdas, kehidupan yang cerdas, dan pemerintahan yang cerdas (Triyandra \& Rimayanti, 2017).

Dalam konteks Indonesia, kota-kota besar yang ada saat ini telah menggunakan teknologi sebagai penunjang kemajuan kota dalam segala bidang. Beberapa kota besar di Indonesia sudah menerapkan konsep smart city, di antaranya adalah Jakarta, Bandung, Surabaya, Yogyakarta, Malang, Balikpapan, dan Makasar (Triyandra \& Rimayanti, 2017) serta Pekanbaru. Kota Pekanbaru mengusung tagline Smart City Madani (Meiwanda, 2020). Artinya, bagi banyak kota di Indonesia bahkan dunia, konsep kota pintar menjadi alternatif penting untuk menjawab permasalahan perkotaan yang selama ini tidak terurai.

Pekanbaru sebagai ibukota Provinsi Riau mengalami perkembangan yang sangat pesat. Seiring dengan perkembangannya, Pekanbaru juga melakukan peningkatan pelayanan dengan menggunakan teknologi untuk mempermudah masyarakat dalam menjalankan aktivitas. Teknologi yang dibuat sebagai inovasi dan sarana dalam menunjang kegiatan perekonomian masyarakat di kota Pekanbaru. Saat ini, pemerintah Kota Pekanbaru memberikan inovasi yang cepat, tepat, dan akurat. Hal ini dilakukan untuk mendukung percepatan visi-misi mewujudkan kota Pekanbaru sebagai Smart City yang madani. Maka, pemerintah kota meluncurkan program Smart Card Madani (Pemko Pekanbaru, 2019: diakses melalui http://pekanbaru.go.id tanggal 10 Februari 2018).

Smart Card Madani adalah inovasi kartu pintar sebagai bagian dari pelayanan prima yang dihadirkan untuk masyarakat. Konsep pelayanan terintegrasi melalui kartu tersebut digadang-gadang mampu menyelesaikan permasalahan kota. Sederetan manfaat dari program smart card ini adalah kemudahan akses pelayanan di bidang pendidikan, pemerintahan, 
kesehatan, transportasi, dan perizinan (Pemko Pekanbaru, 2019: diakses melalui http://pekanbaru.go.id tanggal 30 April 2020), bahkan pelayanan parkir, jajan di sekolah bagi siswa, dan pembayaran retribusi pasar. Menurut data tahun 2018, bahwa pemerintah Kota Pekanbaru telah membagikan 10.000 kartu pintar kepada masyarakat, ASN, dan siswa (Deni Hidayat: Sepuluh Ribu Masyarakat di Pekanbaru Gunakan Smart Card Madani, 2018, diakses melalui kiblatriau.com/news tanggal 30 April 2020),

Program Smart Card Madani merupakan salah satu dari konsep Smart City. Program ini merupakan inovasi daerah yang telah diatur dalam UU No. 23 tahun 2014 tentang pemerintahan daerah dalam bab XXI bertajuk inovasi daerah pasal 386- 390. Dalam undangundang tersebut dikatakan bahwa pemerintah daerah harus melakukan inovasi yang menunjang pembangunan daerah. Konsep ini merupakan impian bagi kota-kota di Indonesia karena diyakini bisa menyelesaikan berbagai masalah perkotaan seperti kemacetan, penumpukan sampah, dan keamanan warga. Konsep smart city ini juga sudah diterapkan di berbagai kota besar di Indonesia (Triyandra \& Rimayanti, 2017), sebagai produk inovasi. Dalam konteks ini, inovasi dipahami sebagai "an idea, practice, or object perceived as new by the individual." (Suatu gagasan, praktek, atau benda yang dianggap/dirasa baru oleh individu) (Rogers, 1962). Oleh karena itu, bagaimana ide-ide baru, hal praktis atau objek tertentu dapat diadopsi oleh individu-individu dan organisasi (Wahid \& Amalia, 2020).

Program Smart Card Madani diluncurkan pada bulan Agustus 2017 oleh pemerintah kota Pekanbaru. Program ini dijalankan oleh Dinas Komunikasi, Informatika, Statistik dan Persandian (Diskominfo), Bidang Penyelenggara e-Government yang bekerja sama dengan bank BNI untuk menjalankannya. Melalui peraturan Walikota Pekanbaru Nomor 107 Tahun 2016 bab IV bagian keempat mengenai tugas dan fungsi bidang penyelenggara e-Government yaitu melakukan penyiapan, perumusan, dan pelaksana kegiatan di bidang infrastruktur dan teknologi, pengembangan pengelolaan aplikasi serta keamanan informasi dan komunikasi. Fakta ini hadir karena konsep internet of things (IoT) yang mengintegrasikan teknologi dalam tata kelola kota. Peningkatan efisiensi, diseminasi informasi, respon cepat, dan perbaikan pelayanan untuk meningkatkan kualitas dan kesejahteraan masyarakat adalah sederetan tujuan dari integrasi teknologi (Wahid \& Amalia, 2020).

Studi dan diskursus tentang smart city telah banyak dilakukan dengan beragam variannya. Nam dan Pardo melihat smart city sebagai inovasi perkotaan yang memfokuskan pada tiga unsur yakni manajemen, kebijakan, dan konteks (Nam \& Pardo, 2011). Smart city berkaitan dengan penggunaan teknologi berupa komputer pintar untuk membuat infrastruktur kota yang kritis meliputi administrasi kota, pendidikan, kesehatan, keselamatan publik, real estate, transportasi, dan pemanfaatannya-lebih cerdas, saling berhubungan, dan efisien (Alawadhi et al., 2012). Konotasi kota cerdas mewakili kota inovasi. Label smart city menunjuk pada inovasi untuk bertransaksi. Pada kota pintar dibutuhkan inovasi sektor publik yang didukung teknologi informasi dan komunikasi sebagai infrastruktur pengaturan kota (Nam \& Pardo, 2011). Teknologi informasi dan komunikasi yang semakin pesat menurut Nainggolan, menimbulkan revolusi baru berupa peralihan sistem kerja dari konvensional ke era digital, melalui e-Government (Nainggolan \& Sd, 2018). Konsep yang demikian ini, disebut dalam penelitian Shelton sebagai kota akademis yang berilmu, bukan hanya sebagai hamparan imajinasi (Shelton et al., 2015). Washburn (lihat Alawadhi et al., 2012) dalam 
studinya juga menjelaskan bahwa, 'kota pintar' berkembang sebagai pendekatan baru untuk memitigasi dan memperbaiki masalah perkotaan dan membuat pembangunan kota lebih berkelanjutan yang didukung teknologi. Teknologi dianggap sebagai salah satu komponen inti dari kota cerdas.

Konsep kota pintar fokus pada peningkatan kualitas hidup manusia dan secara signifikan meningkat pada abad terakhir terutama karena meningkatnya akses pelayanan. Namun demikian, industrialisasi yang berat dan populasi yang terus bertambah di daerah perkotaan telah menjadi tantangan besar di bidang administrasi, arsitek, dan perencanaan kota (Eremia et al., 2017). Studi ini bertujuan untuk mendiskusikan penggunaan smart card Madani sebagai solusi permasalahan kota Pekanbaru. Adapun teori yang digunakan dalam artikel ini adalah teori difusi inovasi Gabriel Tarde yang kemudian dikembangkan oleh Everett $\mathrm{M}$. Rogers pada tahun 1960-an (Pamungkas, 2018 dan Aji \& Slamet, 2019).

Artikel ini merupakan bagian dari domain komunikasi pembangunan yang menggunakan teori difusi inovasi. Teori ini sangat tepat diterapkan dalam konteks komunikasi pembangunan, khususnya di negara-negara sedang berkembang seperti Indonesia. Istilah pembangunan dianggap sebagai cara yang tepat untuk menyelesaikan berbagai masalah di masyarakat. Saat ini, peran komunikasi dianggap sangat penting, terutama dalam pembangunan (Akbar et al., 2019). Komunikasi pembangunan bertujuan untuk menyampaikan, mengkaji, dan menjelaskan tentang suatu isu serta gagasan aktual yang berkaitan dengan perubahan menuju pembangunan masyarakat. Komunikasi pembangunan merupakan strategi komunikasi seluruh komponen masyarakat dari sebuah rencana pembangunan nasional (Wibowo, 2019).

Dalam konteks ini, Rogers menyebutkan bahwa pembangunan merupakan suatu proses perubahan sosial dengan partisipasi masyarakat yang luas. Hal ini dilakukan untuk kemajuan sosial dan material melalui pengawasan yang lebih besar dari lingkungan mereka. Perubahan dimaksudkan menuju pola-pola masyarakat yang memungkinkan realisasi yang lebih baik dari nilai-nilai kemanusiaan yang berlaku (Wijaya, 2015). Oleh karenanya diperlukan penyebaran inovasi yang menyeluruh pada seluruh komponen masyarakat. Sehingga inovasi berdampak terhadap perubahan sosial masyarakat secara integratif dan partisipatif.

Pendekatan komunikasi pembangunan partisipatif secara kontinyu perlu terus dikembangkan untuk memberdayakan masyarakat tingkat bawah melalui pendekatan pendidikan nonformal (Amanah, 2010) dengan tujuan mendidik dan memotivasi masyarakat (Sucahya \& Surahman, 2017). Gagasan baru sebagai inovasi yang berdampak pada perubahan sosial harus dikomunikasikan kepada masyarakat. Masyarakat sebagai penerima inovasi sebaiknya tidak hanya mengetahui perubahan, tapi juga harus mendukung dan terlibat sehingga mereka menjadi bagian dari perubahan tersebut. Suatu masyarakat, organisasi, kelompok, atau individu dapat meniru dan mengadopsi bentuk inovasi yang dikembangkan (Sucahya \& Surahman, 2017), termasuk smart card yang dihadirkan pemerintah Kota Perkanbaru. Pada prinsipnya kartu pintar ini diperuntukkan bagi masyarakat untuk kemudahan akses layanan pemerintahan.

Teori difusi inovasi digunakan untuk melihat sejauh mana individu atau kelompok mengadopsi sebuah inovasi. Inovasi adalah gagasan, pengetahuan, dan teknologi (Pamungkas, 2018). Teori ini menjelaskan bagaimana, kenapa, dan di tingkat apa suatu inovasi dan 
teknologi tersebar. Menurut Rogers, inovasi harus disebarkan secara berkelanjutan melalui saluran tertentu kepada masyarakat dalam sistem sosial (Aji \& Slamet, 2019) pada sebuah kurun waktu (Safril, 2019). Difusi inovasi menjadi dasar untuk mendukung keputusan para pemangku kepentingan dengan menggabungkan pengaruh yang saling menyeimbangkan dari tingkat inividu, kelompok, dan sistem yang menjelaskan perubahan organisasi dan mengurangi ketidakpastian (Wibowo, 2019).

Teori ini memiliki empat elemen pokok yakni inovasi, saluran komunikasi, waktu, dan sistem sosial (Sari, 2016; Rusmiarti, 2016; dan Wahid \& Amalia, 2020). Inovasi diartikan sebagai temuan baru sebagai gagasan, ide (Pamungkas, 2018) maupun produk yang dihadirkan oleh pemerintah. Kreasi ini dalam bentuk produk yakni smart card Madani. Inovasi juga memiliki empat ciri yang dapat diadopsi yaitu (1) relative advantage (keuntungan relatif), (2) compatibility (kesesuaian), (3) complexity (kerumitan), (4) triablity (siap uji) (Pamungkas, 2018 dan Akmalia \& Rikumahu, 2020).

Pertama, keuntungan relatif, merupakan tingkatan suatu inovasi yang dianggap lebih baik daripada ide, gagasan, maupun produk yang ada sebelumnya. Derajat keuntungan relatif dapat diukur secara ekonomis, tetapi prestasi sosial, kenyamanan, dan kepuasan juga merupakan unsur penting. Kedua, kesesuaian, adalah derajat inovasi dianggap konsisten dengan nilai-nilai yang berlaku, pengalaman dan kebutuhan mereka yang menerima. Ketiga, kerumitan, adalah suatu tingkatan inovasi dianggap relatif sulit dimengerti dan dipergunakan. Kesulitan untuk dimengerti dan digunakan akan merupakan hambatan bagi proses penerimaan inovasi. Keempat, kemungkinan untuk dicoba, adalah suatu tingkat inovasi dieksperimentasikan pada landasan terbatas. Kelima, mudah diamati, adalah suatu tingkat hasil-hasil suatu inovasi dapat disaksikan oleh orang lain (Pamungkas, 2018).

Oleh karena itu, studi ini mengajukan pertanyaan bagaimana smart card Madani yang dihadirkan oleh Pemerintah Kota Pekanbaru dapat memberikan pelayanan publik secara digital sehingga mengurangi permasalahan masyarakat? Tujuan penelitian ini terlihat dari manfaat yang dirasakan oleh masyarakat Kota Pekanbaru dalam bentuk pelayanan publik melalui program smart card Madani.

\section{METODE PENELITIAN}

Artikel ini menggunakan paradigma penelitian kualitatif. Studi ini berusaha menggambarkan, meringkas berbagai situasi dan kondisi atau fenomena yang menjadi objek penelitian (Bungin, 2008). Data dikumpulkan dengan menggunakan observasi, wawancara, dan dokumentasi dari lokasi penelitian termasuk informan. Data yang bersumber dari observasi dan dokumentasi sangat penting untuk menvalidasi data wawancara dari informan. Data dikumpulkan dari latar data (data setting) yang berbeda. Latar data yang dimaksud adalah latar natural (natural setting) yaitu fenomena atau peristiwa secara normal terjadi (Silalahi, 2012). Informan penelitian merupakan orang yang dimanfaatkan untuk memberikan informasi tentang situasi dan kondisi latar belakang penelitian yakni orang yang benar-benar mengetahui permasalahan penelitian. Informan dipilih dengan teknik purposif, yaitu menentukan kelompok peserta yang menjadi informan sesuai dengan kriteria terpilih yang relevan dengan masalah penelitian (Bungin, 2008). Informan dipilih berdasarkan pertimbangan subjektif, yakni berdasarkan posisi informan yang berkaitan langsung dengan penelitian ini. Informan terpilih yaitu Deni 
Hidayat, Kabid Penyelenggaraan E-Government dan Teknologi Informatika dan Firmansyah Eka Putra, Kepala Dinas Komunikasi Informasi Statistik dan Persandian Kota Pekanbaru.

\section{HASIL DAN PEMBAHASAN \\ Konsep Smart Card Madani}

Banyak studi menyebutkan bahwa smart city sangat didukung oleh penggunaan teknologi informasi (Ardiani, 2018; Noor, 2018; dan Imran \& Armawan, 2019) terutama kaitannya dengan big data yang diperlukan secara digital (Wahyudin, 2018 dan Suharmanto, 2019) sebagai inovasi bagi masyarakat urban (Nam \& Pardo, 2011). Kota-kota di belahan dunia termasuk Indonesia mulai menerapkan kota pintar berbasis teknologi untuk menyelesaikan permasalahan yang dihadapi masyarakat perkotaan (Hasibuan \& Sulaiman, 2019). Konsep kota pintar menghadirkan layanan kepada masyarakat dengan tujuan efisiensi waktu dan efektivitas kerja. Dalam konteks Kota Pekanbaru, bentuk implementasi smart city salah satunya adalah produk Smart Card Madani. Produk ini hadir untuk memberikan kemudahan akses layanan dalam berbagai bidang.

Smart Card Madani memiliki banyak fungsi di antaranya sebagai alat transaksi banking maupun non-banking dan pelayanan publik di lingkungan pemerintahan kota Pekanbaru. Selain itu, smart card ini dijadikan sebagai kartu identitas bagi masyarakat serta berfungsi sebagai pengganti uang tunai (Pemko Pekanbaru, 2019: diakses melalui http://pekanbaru.go.id tanggal 10 Februari 2018). Bagi masyarakat, produk kartu pintar Madani dapat digunakan sebagai alat transaksi menabung dan difungsikan sebagai Anjungan Tunai Mandiri atau Automatic Teller Machine (ATM) (Wikipedia, 2019: diakses melalui http://id.wikipedia.org/wiki/ATM tanggal 22 Agustus 2019). Produk ini memudahkan masyarakat dalam mendapatkan pelayanan publik lebih cepat dan lebih baik, tanpa antre, dan tanpa mengisi formulir manual.
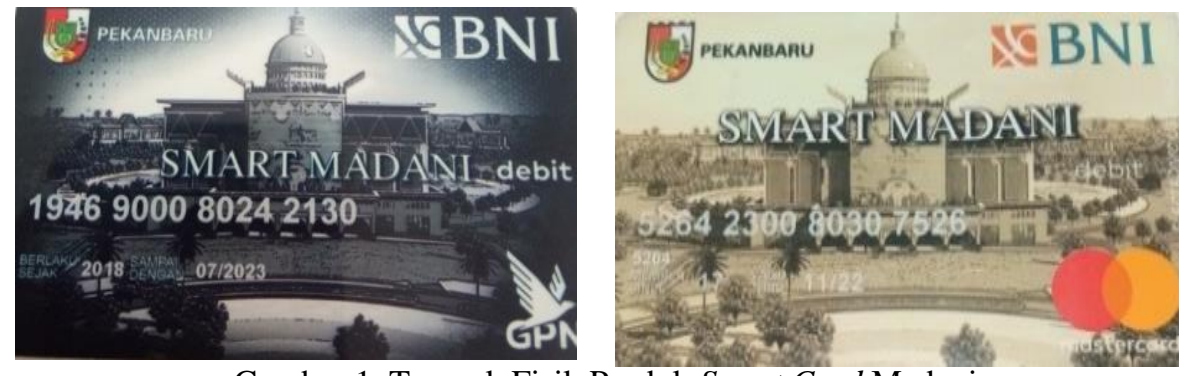

Gambar 1. Tampak Fisik Produk Smart Card Madani.

Sumber: Dokumentasi Hasil Penelitian, 2019.

Smart Card Madani adalah salah satu produk inovasi pemerintah Kota Pekanbaru yang hadir dengan mempertimbangkan perkembangan teknologi di era milenial dan digital. Awalnya, pada tahun 2016, pemerintah Kota Pekanbaru mulai merancang hingga akhirnya dilaunching pada bulan Agustus 2017. Menurut Putra, program ini baru efektif penggunaannya di bulan Januari 2018 dan mulai didistribusikan terutama ke pegawai pemerintahan. Pada tahun itu pula telah didistribusikan ke masyarakat yang dilakukan pihak bank dengan cara mengganti kartu ATM lama dengan kartu Smart Card Madani (Putra, wawancara: 2019). 
Pada tahun 2018, pemerintah Kota Pekanbaru telah mencetak produk smart card sebanyak 500.000 yang siap digunakan warga Pekanbaru. Menurut data, bahwa hingga tahun 2019, seluruh masyarakat yang telah menggunakan produk ini tercatat sebanyak 50.000. Sedangkan untuk kalangan ASN kota Pekanbaru sebanyak 8.351. Pada tahapan akhir kegiatan, pemerintah kota melaunching penerapan kartu ini di SMPN 4 Pekanbaru yang kemudian juga akan diterapkan di SMPN 1, SMPN 5, dan SMPN 10 Pekanbaru. Melalui program ini, siswa mendapatkan banyak manfaat di antaranya sebagai fungsi identitas, sebagai tabungan, dan berbagai akses di bidang pelayanan pendidikan, kesehatan, pemerintahan serta transportasi (Hidayat: wawancara, 2019). Inovasi ini dibuat untuk membantu pemerintah dalam membangun daerah, khususnya untuk mempermudah segala urusan yang dilakukan di lingkungan pemerintah kota Pekanbaru.
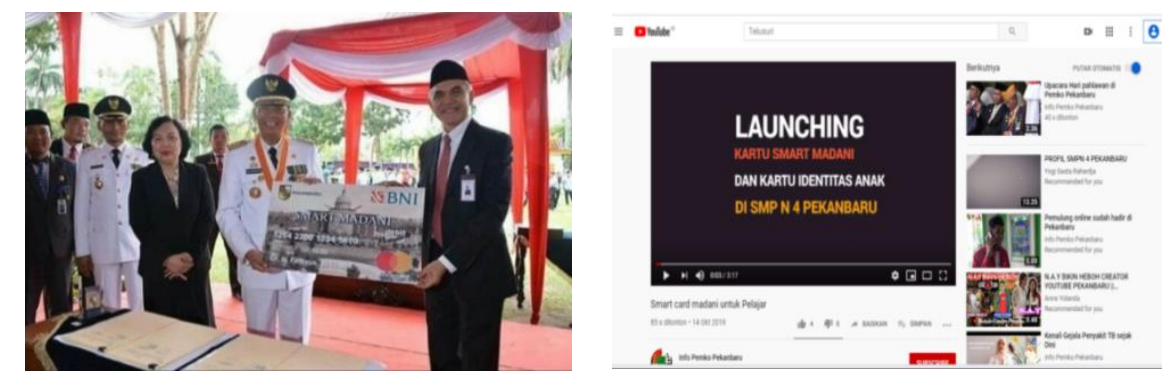

Gambar 2. Launching Perdana Smart Card Madani pada HUT RI ke 72

Sumber: Dokumentasi Hasil Penelitian, 2019.

\section{Difusi Smart Card Madani}

Pihak yang terlibat di dalam program ini dari awal perencanaan, pembentukan hingga sosialisasi dan implementasi tidak sedikit. Program ini memang terintegrasi pada seluruh pelayanan melalui pemanfaatan teknologi. Pihak-pihak yang terlibat merupakan sistem sosial yang sangat kompleks (Gunawan, 2019; Pamungkas, 2018; dan Akmalia \& Rikumahu, 2020) yang secara terus menerus membangun tatanan baru yang lebih modern. Demikian juga untuk perannya sebagai agen sosialisasi di masyarakat yang terstruktur dan massif, melekat pada pemerintah. Pihak-pihak seperti Dinas Komunikasi, Infomasi, Statistik, dan Persandian Kota Pekanbaru, Dinas Catatan Sipil, bank BNI, dan dinas lainnya memiliki andil atas lahirnya produk ini. Kemudian pihak lain seperti sekolah, bus trans metro, pihak merchant, dan masyarakat di samping sebagai adaptor/pengguna inovasi namun sekaligus juga sebagai agen sosialisasi (Putra, 2019).

Keterlibatan pihak-pihak dalam menjalankan program ini sesuai dengan tugas dan perannya masing-masing. Semua memiliki peran yang sangat penting untuk mensukseskan progam smart card agar berjalan dengan baik. Keterlibatan pihak bank adalah membuat dan mencetak kartu, sementara Dinas Kominfo menggunakan teknologi untuk melakukan rekayasa dengan menyisipkan data pada kartu itu. Selanjutnya, mereka mengembangkan aplikasi yang bisa membaca data dari kartu pintar. Dinas Disdukcapil bertugas sebagai penyedia data KTP yang diinput ke dalam smart card. Setiap orang pemilik KTP elektronik datanya dikoneksikan ke dalam kartu pintar ini. Selain itu, prosesnya juga melibatkan Organisasi Perangkat Daerah (OPD) yang menggunakan kartu ini untuk pelayanan, seperti sebagai presensi dan pembayaran tunjangan honor (Putra, 2019). 
Selain pemerintah, pihak lain yang terlibat seperti beberapa sekolah juga menggunakan kartu ini untuk presensi siswa. Kartu pintar juga digunakan pada bus Trans Metro Pekanbaru, hingga merchant sebagai penyedia pedagang untuk menjual barang dan masyarakat sebagai pengguna. Kerjasama juga dibangun dengan tempat yang bisa mengisi uang elektronik, seperti indomaret dan alfamart. Keduanya sebagai mercant dan stakeholder yang turut serta dalam melakukan sosialisasi inovasi ini. Masyarakat sebagai pengguna kartu pintar sekaligus penerima manfaat dari hadirnya Smart Card Madani (Putra, 2019). Kartu pintar atau Smart Card Madani milik pemerintah Kota Pekanbaru merupakan produk inovasi yang terus disosialisasikan kepada masyarakat umum. Pemerintah bekerja sama dengan Badan Pendapatan Daerah (Bapeda), yang diminta untuk menyediakan fasilitas tempat dan mereka juga ikut serta dalam retribusi. Dinas Kominfo memiliki tugas sebagai pengatur dalam retribusinya sedangkan database kartu penduduknya digawangi oleh Disdukcapil (Hidayat, 2019).

Masyarakat menginginkan pemerintah membangun daerah agar bisa berkembang dan maju. Konsep ini sinergi dengan istilah kota pintar yang menggunakan teknologi komunikasi dan informasi. Dengan media digital berupa internet, lewat mobile devices yang dimiliki seperti handphone, ipad, dan laptop masyarakat mendapatkan informasi dari sumber manapun dengan cepat, mudah dan sederhana, mirip dengan istilah digital city-layanan berbasis internet yang memungkinkan konektivitas di mana-mana. Masyarakat di wilayah itu terhubung dengan komunikasi infrastruktur terpadu; fleksibel, berorientasi-layanan infrastruktur komputasi didasarkan pada standar industri terbuka,dan layanan inovatif untuk memenuhi kebutuhan semua pihak (Ardiani, 2018). Fungsi ruang dalam kota pun akan banyak berubah menyesuaikan dengan kebutuhan gaya hidup manusia yang juga ikut berubah. Konsep ini menghasilkan lingkungan perkotaan yang sangat fleksibel dalam ruang dan perubahan dari waktu ke waktu. Semua pekerjaan menjadi efektif dan efisien (Ardiani, 2018).

Masyarakat Kota Pekanbaru sebagai penerima manfaat dari kartu pintar turut merasakan perubahan pola dan sistem pelayanan yang berbasis internet. Masyarakat menerima kehadiran kartu pintar Madani yang menjadi program unggulan pemerintah. Inovasi ini diadopsi karena masyarakat urban memahami arti penting tatanan baru kota pintar (Noor, 2018). Masyarakat mendapatkan informasi penggunaan kartu pintar yang telah digagas pemerintah melalui beragam sumber, misalnya media sosial, media massa, selebaran, spanduk, dan lainnya. Produk ini didistribusikan melalui bank yang difungsikan seperti ATM (Putra, 2019).

Produk yang dihadirkan berupa kartu pintar Madani memiliki konsekuensi pada masyarakat tentang 'budaya baru'. Perubahan perilaku menjadi lebih baik menjadi harapan pemerintah untuk menjadi penilaian berhasil atau tidak program yang dibuat. Misalnya mengubah perilaku pegawai, yang biasanya datang tidak pada awal waktu. Dengan adanya kartu ini, pegawai hanya menempelkan kartu pada aplikasi yang telah disediakan maka tercatat pada jam berapa masuk dan pulang. Pada praktiknya akan mengubah perilaku orang untuk lebih disiplin dan taat kepada regulasi. Konsep ini akan mendorong pada kristalisasi budaya digital. Bagaimana kesiapan manusia mengadopsi sekaligus menggunakan alat-alat elektronik untuk mempermudah segala urusan. Kemudahan transaksi tanpa uang tunai merupakan budaya baru, untuk mengganti kebiasaan lama (Putra, 2019). 
Masyarakat yang menerima produk baru memiliki kondisi yang sangat beragam. Sebagai sistem sosial, masyarakat dipengaruhi oleh banyak faktor seperti psikologi, sosial, dan politik yang setiap orang berbeda walau dalam satu komunitas. Kompleksitas ini tak lain karena khalayak bukanlah hanya sekedar benda dan penerima konten (Nasrullah, 2018), namun terus mengalami perkembangan yang dinamis. Pada akhirnya, masyarakat menerima informasi untuk membangun kreativitas karena hadirnya teknologi komunikasi dan informasi sehingga menjadi budaya baru (Fauzi, 2017).

Pemerintah memiliki harapan yang tinggi dari program smart card ini terutama terkait dengan konsep layanan prima kepada masyarakat. Feedbacknya adalah kepuasan masyarakat karena pelayanan yang diberikan pemerintah. Artinya, jika pemerintah memberikan pelayanan yang baik maka masyarakat merasakan kepuasan. Pelayanan prima melalui berbagai program pemerintah saat ini sangat didukung kemajuan teknologi (Saptadi et al., 2019) apalagi pada pembangunan masyarakat pedesaan (Badri, 2016) juga pada dunia perbankan (Akmalia \& Rikumahu, 2020). Era globalisasi digital telah mampu mengubah paradigma pemerintah terhadap kontribusi teknologi informasi sehingga dapat memberikan pelayanan yang cepat, tepat dan akurat. Tren pada tata kelola smart city juga akan meningkatkan partisipasi masyarakat dan pemerintahan dalam memanfaatkan data aplikasi, memberikan saran maupun kritikan secara cepat, mudah dan akurat (Saptadi et al., 2019). Kepuasan dan kepercayaan masyarakat dalam hubungannya dengan pemerintah akan menjadi kekuatan terkait eksistensi pemerintah dalam bentuk dukungan moril masyarakat (Putra, 2019).

Semua elemen harus terus bersinergi dalam mewujudkan kebudayaan baru berbasis teknologi. Pada konteks ini, Dinas Komunikasi, Informasi, Statistik dan Persandian Kota Pekanbaru sebagai pelaksana program adalah garda terdepan dalam mensukseskan program ini. Komunikasi Inovasi yang dilakukannya untuk menunjang keberhasilan program Smart Card Madani tentunya tidak terlepas dari teori difusi inovasi yang di kemukakan oleh Everett M. Rogers. Smart card adalah sesuatu inovasi berupa ide, perilaku, produk, informasi, dan praktek-praktek baru yang diterima, digunakan, dan dilaksanakan oleh masyarakat dalam suatu lokalitas tertentu. Produk inovasi ini digunakan untuk mendorong terjadinya perubahan di segala aspek kehidupan masyarakat demi terwujudnya mutu hidup setiap individu dan seluruh masyarakat.

\section{Penerapan Smart Card Madani sebagai Solusi Permasalahan Kota}

Konsep 'kota pintar' berkembang sebagai pendekatan baru untuk mitigasi dan perbaikan masalah perkotaan saat ini dan membuat pembangunan perkotaan lebih berkelanjutan (Alawadhi et al., 2012). Kota pintar yang diidamkan setiap wilayah membutuhkan inovasi berbasis teknologi. Smart Card merupakan ide atau inovasi baru yang lahir bersama dengan kemajuan teknologi informasi dan komunikasi. Smart Card Madani adalah kartu pintar berbasis teknologi untuk mewujudkan efisiensi pelayanan bagi masyarakat luas. Kartu pintar dianggap sebagai langkah positif untuk memanfaatkan kemajuan teknologi digital secara efisien dan efektif. Penggunaan kartu sebagai alat transaksi mengacu pada arah gaya hidup (Ardiani, 2018) yang memiliki banyak keuntungan. Salah satu di antaranya adalah lebih praktis dan aman karena tidak harus membawa uang tunai, serta ekonomis karena penggunaannya akan mendapat keuntungan tersendiri (Putra: wawancara, 2019). 
Produk inovasi dari smart card memiliki banyak fungsi dalam memenuhi kebutuhan pelayanan di Kota Pekanbaru. Dengan memanfaatkan teknologi akan menghadirkan kemudahan segala urusan dalam pemerintahan. Seperti diketahui, bahwa kegunaan dari smart card ini sebagai alat untuk mempermudah dalam memberikan pelayanan pemerintahan. Pelayanan pemerintahan seperti bidang administrasi kota, pendidikan, kesehatan, keselamatan publik, real estate, transportasi dan keperluan kota lainnya (Bajri \& Irwansyah, 2019) dan pada akhirnya gaya hidup manusia berubah dengan hidup di dunia digital internet (Ardiani, 2018). Oleh karena itu, integrasi teknologi bertujuan untuk meningkatkan efisiensi, membagikan informasi pada publik, memperoleh respon cepat, dan memperbaiki pelayanan masyarakat untuk meningkatkan kualitas dan kesejahteraan masyarakat (Wahid \& Amalia, 2020; Hasibuan \& Sulaiman, 2019) di mana penggunaan keseluruhannya harus dilakukan secara cerdas, saling berhubungan dan efisien (Bajri \& Irwansyah, 2019).

Pemerintah dalam konteks ini mencoba menghadirkan konsep yang terintegrasi. Konsep smart city harus mengintegrasikan empat hal yakni, 1) People (pengguna) temasuk karakter dan akhlak, ketaatan terhadap kebijakan; 2) Mekanisme dan standar pelayanan, termasuk pola hubungan antar stakeholder, mekanisme integrasi layanan publik dan data; 3) Infrastructure ICT, untuk mengintegrasikan pelayanan dan data (informasi); dan 4) Struktur kelembagaan smart city untuk melakukan analisator, integrator, evaluator, serta menyelaraskan IT Governance dengan bisnis proses. Kelembagaan smart city akan mengawal keberlanjutan program pembangunan yang telah diinisiasi pemerintah daerah (Hasibuan \& Sulaiman, 2019). Pemerintah mencoba memperbaiki kualitas pelayanan publik yang lumayan sulit dan lambat saat akan mengurus dan mendaftarkan data diri. Dengan begitu lebih mudah memberikan pelayanan, lebih cepat, dan lebih akurat. Kartu pintar ini juga berfungsi sebagai ATM untuk menabung. Selain itu, juga digunakan sebagai uang elektronik untuk belanja, bayar uang parkir, bayar tol dan lainnya. Saat ini pemerintah sedang mengurangi penggunaan uang tunai (Putra: Wawancara, 2019).

Kelebihan kartu ini untuk membantu pemerintah agar mudah memberikan pelayanan dengan cepat dan efektif kepada masyarakat. Kelebihan produk ini adalah mampu mempercepat proses registrasi maupun pelayanan saat mengurus administrasi di pemerintahan dan layanan lainnya. Masyarakat semakin memperoleh kemudahan layanan seperti tidak perlu membawa uang tunai saat melakukan transaksi, bisa digunakan untuk membayar parkir, tol, dan berbelanja. Kartu pintar ini memiliki banyak kelebihan yang sangat membantu masyarakat dalam mendapatkan pelayanan (Putra, 2019).

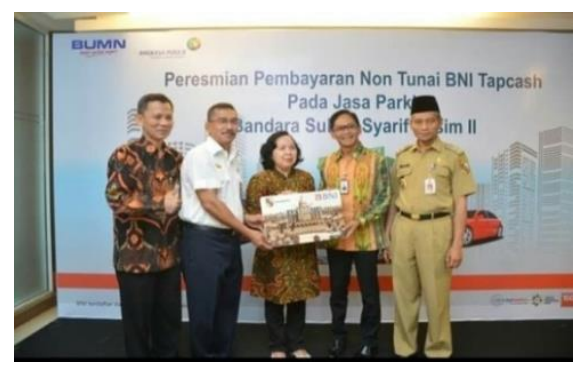

Gambar 3. Peresmian Smart Card Madani di Bandara SSK II Pekanbaru Sumber: Data Hasil Penelitian, 2019. 
Pada awalnya, pemerintah Kota Pekanbaru memfokuskan realisasi penggunaan Smart Card Madani pada tiga instansi pemerintah, yakni Dinas Kesehatan, Dinas Pendidikan, dan Dinas Perhubungan. Ketiga instansi ini dianggap sebagai pusat pelayanan publik yang bersentuhan langsung dengan kebutuhan masyarakat. Pada Dinas Kesehatan, selain untuk pelayanan, kartu ini berfungsi untuk menyimpan data dan perkembangan kesehatan pasien. Setiap pasien memiliki databased yang memuat informasi diri hingga riwayat penyakit yang diderita. Databased tersebut tersimpan dengan baik pada kartu pintar Madani untuk kemudian dapat digunakan pada saat pelayanan kesehatan.

Sedangkan pada Dinas Pendidikan, smart card diterapkan sebagai smart school yang berfungsi sebagai absensi dan alat transaski di kantin sekolah. Bagi para guru, sistem presensi yang biasanya menggunakan finger print atau sejenisnya kini mengalami perubahan. Dengan kartu pintar yang disediakan oleh pemerintah Kota Pekanbaru, guru dapat melakukan presensi dengan menggunakan kartu ini, tak ubahnya seperti kartu identitas yang multifungsi. Demikian juga bagi siswa, kehadiran smart school memberikan perubahan pada sistem pembayaran di kantin-kantin sekolah. Para siswa tidak perlu membawa uang cash sebagai alat transaksi ketika berbelanja, namun cukup dengan memanfaatkan smart school. Pada tahap selanjutnya, kartu ini akan dikembangkan sebagai alat transaksi pada jenis lainnya seperti pembayaran keperluan sekolah.

Program kartu pintar pada Dinas Perhubungan diterapkan sebagai alat transaksi moda transportasi milik pemerintah Kota Pekanbaru, yakni Trans Metro (Pemko, 2018: diakses melalui http://www.riau24.com tanggal 12 Februari 2018). Bagi masyarakat yang memanfaatkan moda transportasi ini tidak perlu melakukan pembayaran secara cash, namun cukup menggunakan kartu pintar, demikian pula bagi seluruh siswa sekolah. Masyarakat diberikan kemudahan pelayanan transaksi dalam bentuk pembayaran nontunai. Bagi masyarakat, program ini sangat dirasakan manfaatnya khususnya di bidang pelayanan administrasi dan transaksi berbasis elektronik.

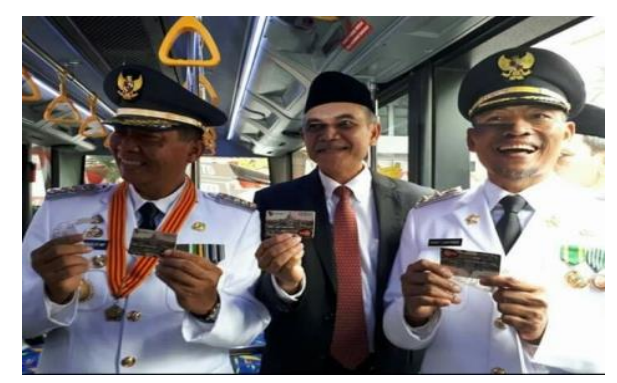

Gambar 4. Uji Coba Smart Card Madani di Bus Trans Metro Pekanbaru.

Sumber: Dokumentasi Hasil Penelitian, 2019.

Smart Card Madani menjadi salah satu program unggulan pemerintah Kota Pekanbaru. Bahkan, program ini dianggap salah satu pencapaian visi untuk mewujudkan kota Pekanbaru sebagai Smart City. Menurut Putra, bahwa program Smart Card Madani merupakan salah satu inovasi Kota Pekanbaru dalam mempercepat smart city (Putra, 2019). Misi dari program ini tentunya untuk memberikan manfaat dan mempermudah masyarakat dalam pengurusan pelayanan administrasi di lingkungan pemerintah Kota Pekanbaru serta mengurangi penggunaan uang tunai. Kartu ini juga dimanfaatkan untuk menyimpan uang. Menurut data 
penelitian, bahwa pada prinsipnya program ini memiliki 3 misi, yakni pertama, program smart card dapat mendorong masyarakat untuk mentradisikan budaya menabung. Kedua, mendorong penggunaan uang elektronik; dan ketiga bagaimana meningkatkan pelayanan publik. Oleh karena itu, konsep yang ditawarkan adalah satu kartu untuk semua urusan (Putra, 2019).

Untuk memenuhi kebutuhan pelayanan di lingkungan pemerintah Kota Pekanbaru, program ini membantu masyarakat dalam pelayanan publik. Kelebihan kartu pintar ini adanya integrasi data seperti nama dan Nomor Induk Kependudukan (NIK) yang melekat pada kartu tersebut. Dengan menempelkan kartu pada aplikasi khusus yang telah disediakan, maka masyarakat sudah dapat mengambil nomor antrian tanpa harus mengisi formulir. Data yang ada pada card itu seperti nama dan NIK sangat efektif digunakan dan tidak perlu membawa KTP. Bahkan untuk pegawai digunakan sebagai absensi dan membayar tunjangan pegawai. Kartu pintar ini dapat meringkas waktu pelayanan, sehingga lebih efektif dan dari sisi waktu lebih cepat (Putra, 2019). Konsepnya satu kartu untuk semua layanan terintegritasi dengan data kependudukan (Hidayat, 2019).

Kemudahan transaksi melalui kartu pintar adalah tujuan dihadirkan smart card Madani di berbagai bidang seperti dalam bentuk e-Wallet, dompet elektronik, uang elektronik, dan juga berisi identitas (Putra, 2019) serta pembayaran retribusi sampah untuk menghindari kecurangan (Hidayat, 2019). Sederetan manfaat dari program ini di antaranya adalah pertama, hubungan antara pemerintah dengan pemerintah. Kartu ini hadir untuk membantu urusan administrasi pemerintahan. Kedua, hubungan antara pemerintah dengan masyarakat dalam meningkatkan pelayanan publik. Misalnya digunakan untuk presensi siswa masuk sekolah yang terintegrasi dalam bentuk laporan kepada orang tua saat kartu itu ditempel pada aplikasi yang telah ditentukan terkait jam berapa mereka masuk dan pulang. Ketiga, hubungan pemerintah dengan bisnis, yakni dalam rangka meningkatkan kualitas pelayanan perizinan, sehingga dapat memicu ekonomi baru seperti tumbuhnya perekonomian digital karena transaksi dilakukan dengan uang elektronik. Konsekuensinya adalah terwujudnya 'budaya baru' akibat penggunaan teknologi (Putra, 2019).

Budaya baru berbasis digital dengan mengandalkan teknologi IoT (internet of things) (Wahid \& Amalia, 2020) sangat penting dalam menghadapi keragamaan permasalahan pada masyarakat urban. Hadirnya perangkat elektronik yang saling terhubung dan mampu mengirim data melalu kartu pintar adalah bagian dari 'budaya baru'. Pekerjaan semakin mudah bahkan dengan meminimalisir campur tangan tenaga manusia (Wahid \& Amalia, 2020). Teknologi informasi komunikasi memiliki potensi untuk mengubah struktur sosial dan organisasi, pada saat bersamaan struktur ini memengaruhi desain, implementasi, dan penggunaan teknologi informasi (Rani, 2017). Dengan demikian, Smart Card Madani yang terintegrasi melalui jaringan internet merupakah salah satu upaya untuk membangun budaya digital di era modern. Semua orang berpikir berbasis IoT sehingga membuat lebih efektif dan effisien dalam melakukan aktivitas.

\section{PENUTUP}

Smart Card Madani adalah produk inovasi yang dirancang untuk mempermudah akses layanan bagi masyarakat Kota Pekanbaru. Hadirnya produk ini dimaksudkan untuk menjawab 
permasalahan yang terjadi dalam kehidupan masyarakat urban, terutama terkait pelayanan dalam seluruh aspek. Smart Card Madani dirancang berbasis terknologi internet untuk memudahkan penyelesaian permasalahan. Walaupun produk ini dianggap belum sempurna namun paling tidak dapat menyelesaikan permasalahan secara efisien dan efektif pada bidangbidang tertentu. Pelayanan pemerintahan seperti bidang administrasi kota, pendidikan, kesehatan, transportasi dan keperluan kota lainnya adalah sederetan manfaat yang dirasakan masyarakat. Program ini pada akhirnya mengubah sikap dan perilaku masyarakat menjadi 'budaya baru' dan gaya hidup manusia digital.

Platform budaya baru yang dilahirkan sebagai inovasi menghadirkan perubahan pada masyarakat urban. Perubahan terjadi melalui proses yang integratif dan partisipatif dengan menggunakan konsep komunikasi inovasi. Perubahan yang dicita-citakan pemerintah diinisiasi melalui pemanfaatan kartu pintar Madani. Komunikasi inovasi merupakan konsep yang sering disandingkan dengan difusi inovasi. Komunikasi memiliki peran menyampaikan pesan berupa inovasi kepada masyarakat agar diadopsi sehingga terjadi perubahan budaya. Dalam konteks ini, pembangunan berkorelasi dengan platform perubahan yang dianggap sebagai cara yang tepat untuk menyelesaikan berbagai masalah di masyarakat. Smart Card Madani adalah produk inovasi yang mengubah sikap dan perilaku masyarakat perkotaan. Perubahan diharapkan menuju pembangunan masyarakat yang cerdas berbasis teknologi.

\section{REFERENSI}

Aji, A. B., \& Slamet, P. U. \& J. (2019). Strategi Difusi Inovasi BKKBN dalam Menjangkau Generasi Digital Natives. Research Fair Unisri, 3(1), Article 1. https://doi.org/10.33061/rsfu.v3i1.2572.

Akbar, M. F., Putubasai, E., \& Asmaria, A. (2019). Peran Komunikasi dalam Pembangunan Masyarakat. Komunika, 2(2), 111-127. https://doi.org/10.24042/komunika.v2i2.6027.

Akmalia, A. N., \& Rikumahu, B. (2020). Analisis Tingkat Adopsi Layanan Perbankan Digital Menggunakan Teori Difusi Inovasi (Objek Studi: Jenius oleh Bank BTPN di Kota Bandung dan Jakarta). Jurnal Mitra Manajemen, 4(8), 1196-1207.

Alawadhi, S., Aldama-Nalda, A., Chourabi, H., Gil-Garcia, J. R., Leung, S., Mellouli, S., Nam, T., Pardo, T. A., Scholl, H. J., \& Walker, S. (2012). Building Understanding of Smart City Initiatives. In H. J. Scholl, M. Janssen, M. A. Wimmer, C. E. Moe, \& L. S. Flak (Eds.), Electronic Government (pp. 40-53). Springer. https://doi.org/10.1007/978-3642-33489-4_4.

Amanah, S. (2010). Peran Komunikasi Pembangunan dalam Pemberdayaan Masyarakat Pesisir. Jurnal Komunikasi Pembangunan, 8(1), Article 1. https://doi.org/10.46937/820105691.

Ardiani, Y. M. (2018). Smart City, Kota Pintar-Sistem dan Perangkat Pendukung. Snatif, 5(1), Article 1. https://conference.umk.ac.id/index.php/snatif/article/view/1.

Badri, M. (2016). Pembangunan Pedesaan Berbasis Teknologi Informasi dan Komunikasi (Studi pada Gerakan Desa Membangun). Jurnal Dakwah Risalah, 27(2), 62-73. https://doi.org/10.24014/jdr.v27i2.2514.

Bajri, R. A. D., \& Irwansyah, I. (2019). Tujuh 'C' dalam Program Humas Jakarta Smart City. Inter Script: Journal of Creative Communication, 1(1), Article 1. https://doi.org/10.33376/is.v1i1.349.

Bungin, Burhan, (2008). Penelitian Kualitatif: Komunikasi, Ekonomi, Kebijakan Publik, dan Ilmu Sosial Lainnya, Jakarta: Kencana. 
Cahyono, A. S. (2016). Pengaruh Media Sosial terhadap Perubahan Sosial Masyarakat di Indonesia. Jurnal Publiciana, 9(1), 140-157-157.

Deni Hidayat, (2018). Sepuluh Ribu Masyarakat di Pekanbaru Gunakan Smart Card Madani, diakses melalui kiblatriau.com/news.

Dr. Rulli Nasrullah, M. S. (2018). Riset Khalayak Digital: Perspektif Khalayak Media dan Realitas Virtual di Media Sosial. Jurnal Sosioteknologi, 17(2), 271-287-287. https://doi.org/10.5614/sostek.itbj.2018.17.2.9.

Eremia, M., Toma, L., \& Sanduleac, M. (2017). The Smart City Concept in the 21 st Century. Procedia Engineering, 181, 12-19. https://doi.org/10.1016/j.proeng.2017.02.357.

Fauzi, R. (2017). Perubahan Budaya Komunikasi pada Pengguna Whatsapp di Era Media Baru. JIKE: Jurnal Ilmu Komunikasi Efek, I(1), Article 1. https://doi.org/10.32534/jike.v1i1.44.

Gunawan, J. (2019). Proses Difusi Inovasi Cek Saldo E-Money pada Aplikasi Cari Aja / Jacksen Gunawan / 60150161 / Pembimbing: Rizal Yussac [Other]. Institut bisnis dan Informatika Kwik Kian Gie. https://doi.org/10/BAB\%20V.docx.

Hasibuan, A., \& Sulaiman, O. K. (2019). Smart City, Konsep Kota Cerdas sebagai Alternatif Penyelesaian Masalah Perkotaan Kabupaten/Kota, di Kota-Kota Besar Provinsi Sumatera Utara. Buletin Utama Teknik, 14(2), 127-135.

Imran, M., \& Armawan, I. (2019). Optimalisasi Smart City sebagai Media Komunikasi Pembangunan di Indonesia. Jurnal KMP (Jurnal Komunikasi Pembangunan), 17(1), $81-85$.

Meiwanda, G. (2020). Challenges of Smart City: Local Government in Pekanbaru City and Community. 40-53. https://doi.org/10.2991/aebmr.k.200301.003

Nainggolan, D. P., \& Sd, Z. R. (2018). Strategi Penerapan E-government di Kota Pekanbaru (Issue 1) [Journal:eArticle, Riau University]. https://www.neliti.comNone.

Nam, T., \& Pardo, T. A. (2011). Smart city as urban innovation: Focusing on management, policy, and context. Proceedings of the 5th International Conference on Theory and Practice of Electronic Governance, 185-194. https://doi.org/10.1145/2072069.2072100.

Noor, S. (2018). Pengembangan Aplikasi Mobile Direktori Kota. Global, 5(2), Article 2. http://www.ejournal.unsub.ac.id/index.php/Fasilkom/article/view/58.

Pamungkas, A. H. (2018). Versi Teori Difusi Inovasi untuk Menafsir Mimpi Kaum Marhaen di Universitas Negeri Padang [Preprint]. INA-Rxiv.

https://doi.org/10.31227/osf.io/dr6zc.

Pemerintah Kota Pekanbaru, (2019). diakses melalui http://pekanbaru.go.id.

Pemerintah Kota Pekanbaru, (2018). diakses melalui http://www.riau24.com.

Rani, S. (2017). Komunikasi Pembangunan dalam Pembangunan Administrasi Melalui Digital Governance. Alhadharah: Jurnal Ilmu Dakwah, 16(31), 66-74. https://doi.org/10.18592/alhadharah.v16i31.1757.

Rogers, Everett M., (1962). Diffusion of innovation, New York, London: Free Press.

Rusmiarti, D. A. (2016). Analisis Difusi Inovasi dan Pengembangan Budaya Kerja pada Organisasi Birokrasi. Masyarakat Telematika Dan Informasi: Jurnal Penelitian Teknologi Informasi dan Komunikasi, 6(2), 85-100. https://doi.org/10.17933/mti.v6i2.77.

Safril, S. (2019). Radio SQ dan Pengembangan Dakwah: Studi Difusi Inovasi tentang Peran Radio SQ 104.3 FM Pangkalpinang dalam Usaha Pengembangan Dakwah Islam di Wilayah Pangkalpinang. Mawa'izh: Jurnal Dakwah dan Pengembangan Sosial Kemanusiaan, 10(2), 291-304. https://doi.org/10.32923/maw.v10i2.889. 
Saptadi, N. T. S., Sampe, F., \& Chyan, P. (2019). Desain Model Tata Kelola Sampah Menuju Smart City. Seri Prosiding Seminar Nasional Dinamika Informatika, 3(1), Article 1. http://senadi.upy.ac.id/prosiding/index.php/senadi/article/view/93.

Sari, D. P. (2016). Analisis Pemanfaatan Smartphone dalam Menerapkan Marketing 3.0 Berdasarkan Teori Difusi Inovasi (Studi Deskriptif Kualitatif) [Thesis, UII]. https://dspace.uii.ac.id/handle/123456789/1763.

Shelton, T., Zook, M., \& Wiig, A. (2015). The 'actually existing smart city.' Cambridge Journal of Regions, Economy and Society, 8(1), 13-25. https://doi.org/10.1093/cjres/rsu026.

Silalahi, Ulber, (2012). Metode Penelitian Sosial, Bandung: Refika Aditama.

Sucahya, M., \& Surahman, S. (2017). Difusi Inovasi Program Bank Sampah (Model Difusi Inovasi Pemberdayaan Masyarakat dalam Pengelolaan Bank Sampah Alam Lestari di Kota Serang Provinsi Banten). Jurnal Ilmu Komunikasi, 8(1), 63-79.

Suharmanto, P. (2019). Artificial Intellegence-Driven Innovation in Smart City. Simposium Nasional Ilmiah \& Call for Paper Unindra (Simponi), O(0), Article 0. https://doi.org/10.30998/simponi.v0i0.370.

Triyandra, A. C., \& Rimayanti, N. (2017). Perencanaan Komunikasi Dinas Komunikasi, Informatika, Statistik dan Persandian Kota Pekanbaru dalam Mensosialisasikan Program Smart City (Issue 2) [Journal:eArticle, Riau University]. https://www.neliti.comNone.

Wahid, U.-, \& Amalia, N. (2020). Tantangan Humas Pemerintah Daerah dalam Upaya Publikasi Inovasi Program Smart City. Nyimak: Journal of Communication, 4(1), 3551. https://doi.org/10.31000/nyimak.v4i1.2300.

Wahyudin, D. (2018). Peluang dan Tantangan "Big Data" dalam Membangun "Smart City" untuk Sistem Transportasi. Jurnal Reformasi Administrasi: Jurnal Ilmiah Untuk Mewujudkan Masyarakat Madani, 5(2), 109-115.

Wibowo, I. T. (2019). Proses Difusi Inovasi Program Sakti (Studi Kasus Proses Difusi Inovasi Program Sistem Aplikasi Keuangan Tingkat Instansi (Sakti) Ditjen Perbendaharaan di D.I. Yogyakarta Tahun 2018). Indonesian Treasury Review: Jurnal Perbendaharaan, Keuangan Negara dan Kebijakan Publik, 4(4), 323-337. https://doi.org/10.33105/itrev.v4i4.139.

Wijaya, I. S. (2015). Perencanaan dan Strategi Komunikasi dalam Kegiatan Pembangunan. Lentera, 17(1), Article 1. https://doi.org/10.21093/lj.v17i1.428.

Wikipedia, (2019). diakses melalui http://id.wikipedia.org/wiki/ATM tanggal 22 Agustus 2019. 